the amyloid plaques and fibrillar structures found in scrapie infected brain and it is clearly necessary to determine the relationship between them. An electron microscopic study of the fibrils found in infected brain extracts, reported at the Ciba meeting, has shown particles similar to those of tobacco mosaic virus from which part of the encapsulating protein has been removed. Are the exposed tails in fact the scrapie specific nucleic acid? It should be possible to answer this question by precise biochemical analysis.

Despite the differences of opinion and interpretation of data the clear message from the Ciba meeting was that with the powerful analytical techniques available the problem of the nature of the agent could be solved within the next few years. We should then have the springboard for attempts to control the diseases caused by this group of agents.

FRED BROWN

Head of Virology Research,

Wellcome Biotechnology Ltd,

Woking,

Surrey GU24 0NQ

\section{Acute stress erosions: can they be prevented?}

Stress erosions are superficial mucosal lesions found mainly in the fundus of the stomach. They occur in most if not all critically ill patients. ${ }^{1}$ Acute gastric ulcers may give rise to bleeding if they erode arterioles in the gastric submucosa, or to perforation (as of the fundus and duodenum in patients with severe burns-the so called Curling's ulcer ${ }^{2}$ ). Both shock and hypotension probably have important roles in the formation of stress lesions, ${ }^{3}$ and many studies have been undertaken to assess the value of antacids and histamine $\mathrm{H}_{2}$ receptor antagonists in preventing them. Do such agents work and is one type better than the other?

Such studies are difficult to analyse because of the heterogeneous nature of the lesions and because the researchers have not always included an untreated control group. Many studies have relied on the presence of occult blood in nasogastric aspirates as evidence of bleeding rather than on endoscopic inspection, although such blood may simply be caused by the trauma. Nevertheless, the balance of evidence has suggested that treatment with $\mathrm{H}_{2}$ antagonists is less efficacious than the frequent administration of antacids. ${ }^{45}$ An exception seems to occur with the bleeding from erosions in fulminant hepatic failure, which is reduced by cimetidine, but with no effect on the overall mortality. ${ }^{6}$

Poleski and Spanier have compared the efficacy of prophylactic antacid with cimetidine in preventing stress erosions in critically ill patients, using gastroscopy to evaluate effectiveness.' Some 44 patients at risk were randomised to receive cimetidine $(300 \mathrm{mg}$ six hourly intravenously initially to a maximum of $400 \mathrm{mg}$ four hourly) or antacid (Mylanta II $30-90 \mathrm{ml} /$ hour), the minimum dose being used to maintain hourly gastric $\mathrm{pH}$ around 4 . Both treatments were equally effective in preventing stress ulcers despite the control of $\mathrm{pH}$ being inferior in the cimetidine group. The authors suggested that measurements of gastric $\mathrm{pH}$ might not fully reflect the beneficial effects of cimetidine, since this is only a concentration measurement and does not reflect volume of acid secreted. Cimetidine might protect the mucosa by decreasing the acid load and also by an intrinsic effect. ${ }^{8}$ They confirmed that appreciable bleeding was rare, for none of their patients developed this despite 13 patients having several fundal erosions on endoscopy.

Possibly also the frequency of stress erosions and bleeding is decreasing because of improved supportive care, ${ }^{910}$ so might it not be wise to identify these critically ill patients who are at the maximum risk and give them prophylaxis? Given the side effects of the $\mathrm{H}_{2}$ receptor antagonists, ${ }^{11-14}$ it seems reasonable to restrict the latter to patients unable to retain antacids. Even the alkalinisation of gastric secretions in the critically ill poses the additional risk of reducing the indigenous flora in the stomach with the overgrowth of potentially pathogenic aerobic bacteria, which may infect vulnerable organs such as the lungs. ${ }^{15}$

Thus the doctor may reasonably restrict the use of antacids and $\mathrm{H}_{2}$ receptor antagonists to those patients in the intensive therapy unit who are at serious risk of haemorrhage secondary to stress erosions. Such patients include those with severe uncontrolled sepsis, acid base disturbances, major organ failure, and extensive trauma including burns and head injuries. Patients having prolonged ventilation for respiratory failure appear to be particularly at risk. ${ }^{16}$ Antacids are preferable to $\mathrm{H}_{2}$ antagonists, which should be used when antacids cannot be given. Whether ranitidine will prove to be safer than cimetidine is uncertain, and only time will tell. ${ }^{17}$ Methyl substituted prostaglandins will shortly be introduced on to the market and one of their selling points will undoubtedly be cytoprotection. Prostaglandins are concerned in the production of mucus, local secretion of bicarbonate, and gastric mucosal blood flow. ${ }^{18}$ How important these factors will be in preventing drug and stress induced gastrointestinal haemorrhage remains to be determined by studies now in progress.

GiLlian C HaNson

Consultant Physician,

Whipps Cross Hospital,

London E11 1NR

B G GAZZARD

Consultant Physician,

Westminster Hospital,

London SW1P 2AP

1 Czaja AJ, McAlhany JC, Pruitt BA Jr. Acute gastroduodenal disease after thermal injury: an endoscopic evaluation of incidence of natural history. N Engl f Med 1974;291:925-9.

2 Pruitt BA, Goodwin CW. Stress ulcer disease in the burned patient. World f Surg 1981;5:209-22.

3 Moody FG, Zalewsky CA, Larsen KG. Cytoprotection of the gastric epithelium. World $\mathcal{F}$ Surg 1981;5:153-63.

4 Stothert JC, Simonwitz DA, Dellinger EP, et al. Randomised prospective evaluation of cimetidine and antacid control of gastric pH in the critically ill. Ann Surg 1980;192:169-74.

5 Weigelt IA, Awbakken M, Geruetz BL, Snyder WH. Cimetidine versus antacid in prophylaxis for stress ulceration. Arch Surg 1981;116:597-602.

6 MacDougall BRD, Bailey AJ, Williams $R$. $H_{2}$ antagonists and antacids in the prevention of acute gastrointestinal haemorrhage in fulminant hepatic failure. Lancet 1977;i:617-8.

7 Poleski MH, Spanier AH. Cimetidine versus antacids in the prevention of stress erosions in critically ill patients. Am $\mathcal{f}$ Gastroenterol 1986;81:107-11.

8 Guth PH, Awes D, Paulsen G. Topical aspirin plus HCL gastric lesions in the rat: cytoprotective effect of prostaglandin, cimetidine and probanthine. Gastroenterology 1979;76:88-93.

9 Skillmann JJ, Bushnell LS, Goldman H, Silen W. Respiratory failure, hypotension, sepsis and jaundice: a clinical syndrome associated with lethal haemorrhage from acute stress ulceration of the stomach. Am $\mathcal{F}$ Surg 1969;117:523.

10 Hastings PR, Skillman JJ, Bushnell LS, Silen W. Antacid titration in the prevention of acute gastrointestinal bleeding. $N$ Engl f Med 1978;298:1041-5.

11 Zeldis JB, Friedman LS, Isselbacher KJ. Ranitidine: a new $\mathrm{H}_{2}$ receptor antagonist. $N$ Engl 7 Med 1983;309:1368-73.

12 Anonymous. Ranitidine (Zantac). Med Let Drugs Ther 1981;24:111-3.

13 Dundee JW, McGowan WA Elwood RJ, Hildebrand PJ. Plasma benzodiazepine concentration following oral administration with and without $\mathrm{H}_{2}$ receptor blockers. Ir f Med Sci 1982;151: 413-4.

14 Spahn H, Mutschler E, Kirch W, Ohnhaus EE, Janisch HD. Influence of ranitidine on plasma metoprolol and atenolol concentrations. Br Med f 1983;286:1546-7.

15 Van Saene HKF, Stoutenbeck Ch P, Miranda DR, Zandstra DF. A novel approach to infection control in the intensive care unit. Acta Anaesthesiol Belg 1983;3:193-208.

16 Schuster DP, Rowley H, Feinstein S, McGue MK, Zuckerman GR. Prospective evaluation of the risk of upper gastrointestinal bleeding after admission to a medical intensive care unit. Am $\mathcal{F}$ Med 1984;76:623-30.

17 McCarthy DM. Ranitidine or cimetidine. Ann Intern Med 1983;99:551-3.

18 Harvey CJ, Rampton DS. Prostaglandins and the gastrointestinal mucosa are they important in its function, disease or treatment? Gastroenterology 1985;89:1162-88. 